\title{
INFLUENCE OF NITROGEN, CALCIUM, AND BORON ON THE NODULATION, YIELD, AND PROTEIN CONTENT OF TROPICAL KUDZU
}

\section{George Samuels and Pablo Landrau, Jr. ${ }^{1}$}

\section{INTRODUCTION}

Tropical kudzu (Pueraria phaseoloides) jaranica, has become important in Puerto Rico as a valuable legume for livestock and the control of soil erosion. Unlike its northern relative, kudzu (Pueraria thunbergiana), which is widely planted in the southern United States, little is known about the response of tropical kudzu to lime and fertilizers.

Telford and Childers $(4)^{2}$ reported that tropical kudzu grew well on a Catalina clay, a lateritic soil with a $\mathrm{pH} 4.5$, on Nipe clay, and on another lateritic soil of $\mathrm{pH} 4.6$ to 5.1 with applications of a complete fertilizer such as $10-10-5$ at the rate of about 400 to 600 pounds per acre. In a greenhouse experiment, Rodríguez (1) obtained significantly higher yields when kudzu was grown at a pH 7.5 as compared with pH 5.2. Landrau, Samuels, and Rodríguez (1) reported significantly higher yields of tropical kudzu on an acid Fajardo clay ( $\mathrm{pH}$ 5.3) when it was limed to $\mathrm{pH}$ 6.5. Smith and Chandler (3) stated that soils of $\mathrm{pH} 5.5$ were best for near maximum growth of kudzu.

In field observations the authors noted that tropical kudzu grown in plots which had recently received nitrogenous fertilizers did not possess as many nodules per plant as those grown in unfertilized or limed plots. Further observations over a period of 6 months revealed an increase in nodulation of the nitrogen-fertilized plants. In view of these observations and the reported good growth of tropical kudzu in acid soils ( $\mathrm{pH} 5.5$ and below), experiments were undertaken to determine the effects of lime, boron, and nitrogen on nodulation and yields of kudzu.

\section{PROCEDURES}

Tropical kudzu was grown in the greenhouse on Lares clay, an acid lateritic clay with a normal field $\mathrm{pH}$ of 4.4 . The 0 to 8 -inch surface horizon of the soil taken from a field cropped to kudzu was air-dried, screened through a $1 / 4$-inch mesh screen, and placed in 1-gallon enameled Mitscherlich pots. The soil in the pots was well mixed with appropriate fertilizers. The tropical kudzu seed were pretreated with a 1:1 sulfuric acid-water solution for one-

${ }^{1}$ Plant Physiologist and Assistant Agronomist, respectively, of the Agricultural Experiment Station, University of Puerto Rico, Río Piedras, P. R. The authors wish to express their appreciation to A. Riera, F. Ascorbe, J. Martínez-Mateo, and C. Rivera Estrada for the chemical analyses of the kudzu plant material.

${ }^{2}$ Numbers in parentheses refer to Literature Cited, p. 80. 
TABLE 1.-Yields of tropical kudzu, protein, and nodules, in response to different fertilizer treatments in greenhouse experiment 1

\begin{tabular}{|c|c|c|c|c|c|}
\hline \multirow{2}{*}{ No. } & \multirow{2}{*}{ Treatment } & \multicolumn{2}{|c|}{$\begin{array}{l}\text { Yield of tropical kudzu } \\
\text { per pot }\end{array}$} & \multirow{2}{*}{$\begin{array}{l}\text { Mean nodules } \\
\text { per plant }\end{array}$} & \multirow{2}{*}{$\begin{array}{l}\text { Mean protein } \\
\text { content of } \\
\text { kudzu; dry } \\
\text { weight basis }\end{array}$} \\
\hline & & Green weight & Dry weight & & \\
\hline & & Grams & Grams & Number & Percent \\
\hline 1 & Control & 28 & 6 & 59 & 15.1 \\
\hline 2 & Nitrogen & 68 & 18 & 10 & 18.2 \\
\hline 3 & Lime & 42 & 11 & 89 & 17.1 \\
\hline 4 & Lime and nitrogen & 77 & 22 & 11 & 17.1 \\
\hline 5 & Lime and boron & 63 & 17 & 5 & 16.9 \\
\hline 6 & General means & 56 & 15 & 37 & 16.9 \\
\hline \multirow{3}{*}{\multicolumn{2}{|c|}{$\begin{array}{l}\text { Least significant differences } \\
\text { needed for comparison at } \\
\text { the: } \\
\text { 5-percent level } \\
\text { 1-percent level }\end{array}$}} & & & & \\
\hline & & 12 & 3 & 32 & 6.7 \\
\hline & & 17 & 4 & 45 & 9.4 \\
\hline
\end{tabular}

TABLE 2.-Yields of tropical kudzu in response to difjerent fertilizer treatments in greenhouse experiment 2

[Three cuttings]

\begin{tabular}{|c|c|c|c|c|c|c|c|c|c|}
\hline \multirow{3}{*}{ No. } & \multirow{3}{*}{ Treatments } & \multicolumn{8}{|c|}{ Mean yield of tropical kudzu per pot on green and dry-weight basis } \\
\hline & & \multicolumn{2}{|c|}{ First cutting } & \multicolumn{2}{|c|}{ Second cutting } & \multicolumn{2}{|c|}{ Third cutting } & \multicolumn{2}{|c|}{$\begin{array}{c}\text { Mean of } \\
3 \text { cuttings }\end{array}$} \\
\hline & & $\begin{array}{c}\text { Green } \\
\text { weight }\end{array}$ & $\begin{array}{c}\text { Dry } \\
\text { weight }\end{array}$ & $\begin{array}{c}\text { Green } \\
\text { weight }\end{array}$ & $\begin{array}{c}\text { Dry } \\
\text { weight }\end{array}$ & $\begin{array}{c}\text { Green } \\
\text { weight }\end{array}$ & $\begin{array}{c}\text { Dry } \\
\text { weight }\end{array}$ & $\begin{array}{c}\text { Green } \\
\text { weight }\end{array}$ & $\begin{array}{c}\text { Dry } \\
\text { weight }\end{array}$ \\
\hline & & Grams & Grams & Grams & Grams & Grams & Grams & Grams & Grams \\
\hline 1 & Lime & 65 & 15 & 132 & 28 & 82 & 23 & 93 & 22 \\
\hline 2 & Lime and boron & 67 & 15 & 136 & 35 & 77 & 21 & 93 & 24 \\
\hline 3 & Boron & 59 & 13 & 131 & 29 & 88 & 24 & 93 & 22 \\
\hline 4 & Nitrogen & 81 & 18 & 140 & 37 & 84 & 23 & 102 & 26 \\
\hline 5 & Control & 65 & 14 & 133 & 34 & 83 & 26 & 94 & 25 \\
\hline 6 & General means & 67 & 15 & 134 & 33 & 83 & 23 & 95 & 24 \\
\hline \multicolumn{2}{|c|}{$\begin{array}{l}\text { Least significant difference } \\
\text { needed for comparison at } \\
\text { the: }\end{array}$} & & & & & & & & \\
\hline \multicolumn{2}{|c|}{5 -percent level } & 14 & 3 & 17 & 4 & 15 & 4 & 24 & 6 \\
\hline \multicolumn{2}{|c|}{ 1-percent level } & 18 & 5 & 23 & 6 & 22 & 6 & 32 & 4 \\
\hline
\end{tabular}

half hour and germinated in paper cups containing Lares soil from a field planted to kudzu. Three healthy plants were transplanted to each container. 
The treatments used for the first experiment are given in table 1, and those for the second in table 2 . All received $\mathrm{P}_{2} \mathrm{O}_{5}$ as 20 -percent superphosphate and $\mathrm{K}_{2} \mathrm{O}$ as 60 -percent muriate of potash at the rate of 100 pounds each per acre. Calcium was applied as calcium carbonate, at the rate of 10,000 pounds per acre; nitrogen as ammonium sulfate, 250 pounds of $\mathrm{N}$ per acre; and boron as borax at 30 pounds per acre.

The kudzu for experiment 1 was harvested at a crop age of 3 months; in experiment 2 it was harvested in three cuttings made 4, 7, and 10 months after planting. Green and dry weights were made of the tops which were

TABLE 3.-Number of nodules found on the tropical kudzu root system in greenhouse experiment 2, as affected by different fertilizer treatments

[Three cuttings]

\begin{tabular}{|c|c|c|c|c|c|}
\hline \multirow{2}{*}{ No. } & \multirow{2}{*}{ Treatments } & \multicolumn{4}{|c|}{ Mean number of nodules per plant for- } \\
\hline & & $\begin{array}{l}\text { First } \\
\text { cutting }\end{array}$ & $\begin{array}{l}\text { Second } \\
\text { cutting }\end{array}$ & $\begin{array}{l}\text { Third } \\
\text { cutting }\end{array}$ & $\begin{array}{l}\text { Mean of } \\
3 \text { cuttings }\end{array}$ \\
\hline 1 & Lime & 151 & 208 & 230 & 196 \\
\hline 2 & Lime and boron & 130 & 206 & 195 & 177 \\
\hline 3 & Boron & 114 & 249 & 200 & 188 \\
\hline 4 & Nitrogen & 22 & 187 & 233 & 147 \\
\hline 5 & Control & 108 & 203 & 219 & 177 \\
\hline 6 & General means & 105 & 211 & 215 & 177 \\
\hline \multicolumn{6}{|c|}{$\begin{array}{l}\text { Least significant difference needed for com- } \\
\text { parison at the: }\end{array}$} \\
\hline \multicolumn{2}{|c|}{5 -percent level } & 42 & 110 & 48 & 48 \\
\hline \multicolumn{2}{|c|}{ 1-percent level } & 61 & 159 & 69 & 69 \\
\hline
\end{tabular}

then analyzed for nitrogen. Protein was calculated as $\mathrm{N} \times 6.25$. The roots were carefully separaied from the soil by washing and counts made of the number of nodules per piant for each treatment. In experiment 1 all treatments were replicated three times; in experiment 2, all treatments were replicated nine times for the first cutting, six times for the second, and three times for the last cutting, as three replications in each cutting were used for the nodule counts.

\section{RESULTS}

The results of the experiments are given in tables 1 to 5 .

The use of nitrogen produced significant increases in yields of kudzu in both green and dry weight (tables 1 and 2). This increase was effective for the first cutting only, as there were no significant increases therefrom in the second or third cuttings, experiment 2, table 2 . Lime produced significant 
yield increases in experiment 1 only, there having been no appreciable differences for experiment 2 in any of the three cuttings. The combination

TABLE 4.-Yields of protein in tropical kudzu in greenhouse experiment 2 , as affected by different fertilizer treatments

[Three cuttings]

\begin{tabular}{|c|c|c|c|c|c|}
\hline \multirow{2}{*}{ No. } & \multirow{2}{*}{ Treatments } & \multicolumn{4}{|c|}{$\begin{array}{l}\text { Mean yield of protein in tropical kudzu, } \\
\text { dry-weight basis, for- }\end{array}$} \\
\hline & & $\begin{array}{l}\text { First } \\
\text { cutting }\end{array}$ & $\begin{array}{l}\text { Second } \\
\text { cutting }\end{array}$ & $\begin{array}{l}\text { Third } \\
\text { cutting }\end{array}$ & $\begin{array}{l}\text { Mean of } \\
3 \text { cuttings }\end{array}$ \\
\hline & & Percent & Percent & Percent & Percent \\
\hline 1 & Lime & 14.9 & 18.5 & 21.4 & 18.27 \\
\hline 2 & Lime and boron & 16.5 & 18.5 & 21.1 & 18.70 \\
\hline 3 & Boron & 16.5 & 17.9 & 19.4 & 17.93 \\
\hline 4 & Nitrogen & 14.4 & 18.0 & 19.8 & 17.40 \\
\hline 5 & Control & 15.9 & 18.8 & 19.4 & 18.03 \\
\hline 6 & General means & 15.6 & 18.3 & 20.2 & 18.1 \\
\hline \multicolumn{6}{|c|}{$\begin{array}{l}\text { Least significant difference needed for com- } \\
\text { parison at the: }\end{array}$} \\
\hline \multicolumn{2}{|c|}{5 -percent level } & 1.4 & 1.4 & 2.0 & 1.2 \\
\hline \multicolumn{2}{|c|}{1 -percent level } & 1.9 & 1.9 & 2.9 & 1.8 \\
\hline
\end{tabular}

TABLE 5.-Variation of soil $p H$ in which tropical kudzu was grown in greenhouse experiment 2, as affected by different fertilizer treatments

[Three cuttings]

\begin{tabular}{|c|c|c|c|c|c|}
\hline \multirow{2}{*}{ No. } & \multirow{2}{*}{ Treatments } & \multicolumn{4}{|c|}{ Mean soil pH after harvesting- } \\
\hline & & $\begin{array}{c}\text { First } \\
\text { cutting }\end{array}$ & $\begin{array}{l}\text { Second } \\
\text { cutting }\end{array}$ & $\begin{array}{c}\text { Third } \\
\text { cutting }\end{array}$ & $\begin{array}{r}\text { Mean of } \\
3 \text { cuttings }\end{array}$ \\
\hline 1 & Lime & 5.6 & 5.7 & 5.6 & 5.6 \\
\hline 2 & Lime and boron & 5.6 & 5.7 & 6.0 & 5.8 \\
\hline 3 & Boron & 5.2 & 5.2 & 5.1 & 5.2 \\
\hline 4 & Nitrogen & 5.0 & 4.8 & 4.9 & 4.9 \\
\hline 5 & Control & 5.2 & 5.1 & 5.1 & 5.1 \\
\hline \multicolumn{6}{|c|}{$\begin{array}{l}\text { Least significant difference needed for com- } \\
\text { parison at the: }\end{array}$} \\
\hline \multicolumn{2}{|c|}{5 -percent level } & 0.7 & 0.3 & 0.4 & 0.2 \\
\hline \multicolumn{2}{|c|}{ 1-percent level } & 1.0 & .4 & .6 & .3 \\
\hline
\end{tabular}

of lime and nitrogen used in experiment 1 did not produce significantly higher yields than did the use of nitrogen alone.

The use of boron in combination with lime in experiment 1 significantly 
increased yields over lime used alone. This increase was not realized in experiment 2 (table 2 ).

Determination of the nodulation counts per plant revealed some very interesting facts. In experiment 1 , where nitrogen had been responsible for yield increases, it also produced a significant decrease in nodules per plant. The control had 59 nodules per plant and the nitrogen-fertilized kudzu only 10 (table 1 ). In the first cutting of experiment 2 the addition of nitrogen reduced the nodules per plant from 108 to 22 (table 3 ); this difference was not significant for the second cutting made 7 months after the nitrogen had been applied. This also held true for the third cutting.

The application of lime increased nodulation over the control in the first cutting in both experiments, the difference being just barely significant at the 5-percent level in experiment 2 and just short of it in experiment 1. In the second and third cuttings of experiment 2 , the number of nodules per plant was about the same for the lime and control treatments (table 3 ). The use of boron with lime gave a significant reduction in nodules per plant in the first experiment, but this was not true for the second experiment wherein neither boron nor boron plus lime produced significant differences in nodule counts.

The use of lime and nitrogen in experiment 1 (table 1) reduced nodules per plant as did nitrogen used alone. Lime in the presence of the nitrogen did not increase the nodulation of the kudzu.

The protein content of the kudzu was highest in experiment 1, where nitrogen was used alone; however, the increase was not significant (table 1). In experiment 2 also, none of the treatments caused significant increases in protein, except for lime in the third cutting; here the increase was just significant at the 5-percent level.

The $\mathrm{pH}$ values of the soil taken after the first cutting in experiment 2 (table 5) showed no significant differences. After the second cutting, the soil under nitrogen treatment with ammonium sulfate decreased in $\mathrm{pH}$. The $\mathrm{pH}$ of the limed soils also increased significantly over the control, as was likewise true for the third cutting. The $\mathrm{pH}$ of the control, 5.1, was somewhat higher than the $\mathrm{pH} 4.4$ of the Lares clay used in experiment 1. The higher $\mathrm{pH}$ of the control in experiment 2 coupled with lack of $\mathrm{pH}$ differences for the soil at the first cutting when limed, may help to explain the failure to obtain significant yield increases in kudzu in experiment 1 .

\section{DISCUSSION}

The effect of nitrogen on tropical kudzu yields and nodulation is of great interest. The yields of kudzu were increased by the addition of nitrogen fertilizer to the soil in the first cutting in both experiments, but the nodulation of the kudzu was drastically reduced. The reduction in nodulation is 
in keeping with the findings of previous workers $(2,5)$ who have shown that the addition of nitrogen to the soil interferes with the fixation of free nitrogen by inoculated legumes, and reduces the number of nodules per plant.

The increased yields of kudzu attributable to the application of nitrogen to the soil were significant for the cutting immediately following the application (the first cutting in both experiments). This indicates that the nitrogèn needs of kudzu, even when well-nodulated, were not satisfactorily supplied by the nitrogen fixed through the nodule mechanism. It seems, therefore, that under field conditions, new stands of tropical kudzu can effectively use more nitrogen than is provided by fixation.

The results of the greenhouse experiments carried out, as well as of field experiments (1), indicates that the use of nitrogen influences yields beneficially for the first cutting of new plantings, despite any adverse effect on nodulation; and that by the time of the second cutting ( 3 months after the first) the nitrogen-treated plants have the same number of nodules per plant as the untreated or limed plants. Tropical kudzu also showed a marked ability to grow well at a soil $\mathrm{pH}$ near 5 and to produce large numbers of nodules per plant as compared with its growth in limed soils. The number of nodules per plant was higher for the control on experiment 2 , with a mean soil $\mathrm{pH}$ of 5.1, than in control of experiment 1 where the soil $\mathrm{pH}$ was 4.4.

\section{SUMMARY}

The use of nitrogen, calcium, and boron as soil treatments influenced tropical kudzu nodulation and yields as follows:

1. Applications of nitrogen reduced nodulation per plant drastically, but increased yields significantly in the first cutting.

2. Lime increased nodulation and yields somewhat, if applied to soil the $\mathrm{pH}$ of which was 4.4 , but when the soil $\mathrm{pH}$ was 5.1 , the increase was barely significant.

3. When used with lime, nitrogen reduced nodulation as much as it did when used alone.

4. Boron or boron with lime had no consistent influence on yields or nodulation.

5. The protein content of the kudzu was not measurably influenced by any of the treatments as compared with the control.

\section{RESUMEN}

El uso de los elementos nitrógeno, calcio y boro influyó sobre la formación de nódulos y sobre el rendimiento del kudzu, como sigue:

1. Las aplicaciones de nitrógeno redujeron drásticamente la formación de nódulos, pero aumentaron significativamente los rendimientos del primer corte. 
2. Cuando se aplicó cal al terreno, ésta aumentó el número de nódulos por planta. Se observó un pequeño aumento en los rendimientos cuando el suelo registraba un $\mathrm{pH}$ de 4.4. En los suelos con un $\mathrm{pH}$ de 5.1 no se pudo apreciar aumento significativo alguno.

3. Las aplicaciones conjuntas de nitrógeno y cal redujeron la formación de nódulos al nivel del tratamiento con nitrógeno solo; a pesar de la presencia de la cal.

4. El boro solo o el boro aplicado conjuntamente con la cal, no influyeron consistentemente sobre la formación de nódulos o sobre los rendimientos.

5. Ninguno de los tratamientos al compararse con el tratamiento testigo influyó, en forma que pudiera medirse, sobre el contenido de proteína en el kudzu.

\section{LITERATURE CITED}

1. Landrau, P., Samuels, G., and Rodríguez, P., The influence of fertilizers, minor elements, and soil ph on the growth of tropical kudzu, J. Agr. Univ. P. R. 37 (1) pp. 81-85, 1953.

2. Normand, A. G., Soil Sci. Soc. Amer. Proc. (1943) 82261944.

3. Smith, R. M. and Chandler, J. V., Tropical kudzu moves into Puerto Rico, Crops and Soils, pp. 12-14, March 1951.

4. Telford, E. A., and Childers, N. F., Federal Expt. Station in Puerto Rico, U.S.D.A. Office of Expt. Sta., Cir. No. 67, 1947.

5. Thornton, G. D., Soil Sci. Soc. Amer. Proc. (1946) 112491947. 